\title{
Digital habits and competences of health professionals the Health Area East of Málaga-Axarquía (Málaga)
}

\author{
Antonia $\mathrm{M}^{\mathrm{a}}$ Fernández-Luque \\ University of Salamanca, \\ Área Este de Málaga-Axarquía, \\ Biblioteca Virtual del Sistema Sanitario \\ Público de Andalucía (BVSSPA) \\ Torre del Mar, Málaga, Spain \\ + 34606888278 \\ antoniam.fernandez.sspa@junt \\ adeandalucia.es
}

\author{
Raquel Gómez Díaz \\ E-lectra Research Group, \\ Faculty of Translation and \\ Documentation, \\ University of Salamanca \\ Francisco Vitoria 6, 37008 \\ Salamanca, Spain \\ +34923294580 \\ rgomez@usal.es
}

\author{
José Antonio Cordón García \\ E-lectra Research Group, \\ Faculty of Translation and \\ Documentation, \\ University of Salamanca \\ Francisco Vitoria 6, 37008 \\ Salamanca, Spain \\ +34923294580 \\ jcordon@usal.es
}

\begin{abstract}
Competences in digital reading and writing - which are included in Information Literacy - are essential to fully participate in the society of knowledge and face new schemes and approaches in educational processes, so as to be able to face the challenges of a global society which is more and more technologically demanding. Training platforms and research, as well as the emergence of digital media and devices that give access to the Internet and allow the management, generation and dissemination of information, are producing changes in the reading and writing habits up to a point that we find ourselves in a new intervention paradigm where translation to digital is unavoidable and irrevocable.

We are interested in knowing the changes that are taking place and how is the transition to the consumption and use of digital information occurring among users of health-sciences libraries, since such libraries are pioneer providers of access to digital media for information users.

To gain insight into the reading, writing and information management practices of health professionals in the East of Malaga Health Area. We used a mixed research methodology approach by using qualitative and quantitative research techniques in different stages. It included a thorough study of the state-of-theart scientific knowledge on digital reading and writing, Computer/Digital Literacy, virtual platforms for Training Management, Ecosystem of Electronic Books, Personal Learning Environments and Management of Knowledge.

We will gather information on professionals regarding their performance in their professional and personal roles by using a specifically designed questionnaire. The population sample consisted of 1300 staff members working in all of the involved job categories. As a result, we expect to be able to establish a diagnosis of the current situation, which allows to design an action plan aimed at enhancing digital literacy specifically in healthcare professionals.
\end{abstract}

Permission to make digital or hard copies of all or part of this work for personal or classroom use is granted without fee provided that copies are not made or distributed for profit or commercial advantage and that copies bear this notice and the full citation on the first page. Copyrights for components of this work owned by others than ACM must be honored. Abstracting with credit is permitted. To copy otherwise, or republish, to post on servers or to redistribute to lists, requires prior specific permission and/or a fee. Request permissions from Permissions@acm.org.

TEEM'16, November 02-04, 2016, Salamanca, Spain

(C) 2016 ACM. ISBN 978-1-4503-4747-1/16/11 ...\$15.00

DOI: http://dx.doi.org/10.1145/3012430.3012653

\section{Categories and Subject Descriptors}

- Social and professional topics Information technology education

\section{Keywords}

Learning; reading; education, continuing; educational measurement; writing; medical writing; medical publishing.

\section{CONTEXT AND MOTIVATION}

In order to be competent in the management of the digital reading and writing, the acquisition of some skills connected with the concept of Information Literacy is needed. Literacy is a concept related to the reading and writing skills. The Information Literacy considers some aspects connected with literacy in the digital field. Being literately competent means "to know when and why the information is needed, where to find it, how to asses it, use it and communicate it in an ethical way'. To have the digital reading and writing skills and abilities is a cornerstone that allows the full participation in the knowledge society [1].

The way towards digitalization in the documentation area started with the digitalization of reference works and dictionaries like Medline-Medlars, which resulted in a prevailing model. Scientific journals followed it, not without some reluctance on the part of the academic authorities who didn't trust the new certification and revision models. In the beginning of the Twenty-First century a selection of journals was published in the electronic format and the number hasn't stopped growing.

In the last years, a new technological environment for reading has been developed, the virtual learning environments and the research, fostered by the appearance of digital supports and devices which grant access to the Internet and allow the management, generation and dissemination of information. It is a trend which has been widespread all over the world and has generated a process of permanent innovation [2].One of the areas most deeply affected by this change has been that of reading and writing, to the point of becoming a new intervention paradigm in which the advance towards digitality is unavoidable. Reference works, first, scientific journals later, books nowadays, witness this process [3].

\section{STATE OF THE ART}

The definitions of the book are divided between those who consider it in its materiality basically, and those who consider it an information carrier from a sociological and semiological point or view. In the technological context, the book and reading have 
changed towards a new ecosystem where all the elements involved in the generation, distribution and dissemination of information are changing [4].

Daniel Cassany, who has studied the contemporary reading practices of the written culture and the spaces where they take place, highlights the changes produced in the supports, discourses and the way to approach them in order to read and/or produce them. For Cassany, reading is the result of multiple elements which vary from one practice to another, but which have the previous experience of each reader as a background. [5;6]. Roger Chartier analyzes the former revolutions of the book which were interpreted as threats but which turned out to be advances in the access to knowledge [7].Guglielmo Carvallo approaches the history of the reading-writing practises, the devices and the fixing support of Eastern texts from parchments to computers. According to Carvallo and Chartier, the focus of the research is the connection between the text and the reader's previous experience which confer different meanings to the written text when faced with different ways of cultural appropriation.

The new generations (born as of the 90's) access these technological transformations in a natural way, resulting in two big groups of individuals, called "digital natives and immigrants" [8]. Considering the changes occurred in many areas of the society, new schemes and approaches have been developed in the educational processes to face the challenges of a global society more and more demanding in the use of technology [9].

To sum up, the changes we have listed have caused modifications in the reading practises and behaviour of the real users of the libraries, especially in the Health Sciences libraries, which were pioneers in providing access to the information included in the most popular Health Sciences data base [10].

\section{PROBLEM STATEMENT}

We know that any professional needs to be technologically literate. The characteristics of the work of health professionals need to constantly have access to updated information, most of it in digital format, so the management of digital skills is essential for these professionals.

\section{RESEARCH, OBJECTIVES, GOALS}

The main aim of this project is to know the degree of competence in digital reading and writing of the Health Area professionals in the Axarquía (Málaga, Spain).

The key question is: Can Health professionals get along well in the digital ecosystem? Do Health professionals know where to find digital information, how to assess, generate, communicate and disseminate it?

To reach the intended aim the following actions have been proposed:

- To know the information needs from the point of view of the personal and professional role of the Health Area professionals of the Axarquía (Málaga, Spain) and study the different profiles, needs and expectations in digital reading and writing.

- To analyze the reading and writing practices and abilities in the different digital environments and in the use of

- To determine the most suitable strategies for the acquisition of competencies in reading and writing among the Health professionals in their professional and personal role.

- To know the investment done by the Public Health System in Information Literacy and evaluate if this investment is the most appropriate to get professionals who are competent in the Knowledge Society.

- To know the use of the digital platforms and the ecosystem of the book among the Health professionals.

- To know the relationship between good practices in the field of training in Information Literacy and the improvement in the digital reading and writing competencies.

Considering the results attained it will be possible to support the decision-making process to improve the management of the knowledge and the technology that the institution has implemented, as well as to know and evaluate the benefits derived for the organization from the training in the Information Literacy.

In the development of the project, different indicators will be established to allow the measurement of the profitability of the training from the Library and that guarantee the quality of the services offered, suggesting a training plan that allows the evaluation and the return of the investment plan in the technological-digital competencies.

Finally a model and a training program will be offered in order to remedy the deficiencies found and contributes to a correct Information literacy of the Health professionals, which extrapolated to other Information Management units.

The objective of the current article is to present the preliminary results obtained after analyzing the responses to a questionnaire designed to detect the use of e-journals among health professionals, which was distributed and received for a period of 6 months in 2016. This work has enabled the detection of possible mistakes in the questionnaire design and its validation.

\section{METHODOLOGY}

The methodological approach to research will be the mixed model [11], using qualitative and quantitative research techniques at different stages. The mixed model has been called the third methodological movement Tashakkori y Teddlie proposing the terminology still in Theoretical

We will analyze the theoretical corpus of the disciplines which analyze the reading-writing and literacy paradigms; psychology, pedagogy, didactics, communication sciences, linguistics, semiology, computer science, library and information science.

An exhaustive study of the state of the issue regarding the scientific knowledge of the digital reading and writing, information/digital literacy, virtual platforms to manage training, ecosystem of the electronic book, personal learning and knowledge management environments will be carried out.

A systematic review of the bibliography in the main sources of the scientific literature in the web, in the catalogues of the libraries, in the repositories, in the specialized data bases, in the social media, specialized web sites, professional contacts, etc. The key words and the identification of the most relevant authors will be determined, setting bibliographical alert hat allow the periodical information updating.

The tools considered for the data collection: interviews, questionnaire, monitoring, and observation sheet. 
Initially, a questionnaire to collect information will be produced. Once it has been passed by the Provincial Ethics Committee in Málaga it will be distributed among the professionals of the East Health Management Area of Málaga-Axarquía. This questionnaire will make possible an analysis of the present situation which contains indicators to value the digital reading and writing among the professionals of the Health Service in the area of Axarquía. The questionnaire will be done with Google Drive allowing the monitoring and automatic storage of the answers. The variables included in the questionnaire: Sociological data (age, gender, professional role), use and access to electronic journals and books, types of access, handling of the resources for the management and training in digital writing.

A case study will be implemented (qualitative research) with semi-structured interviews to detect the main obstacles in the way to literacy in real cases

Later on, a proposal to solve the problems to face for the possible solution of the obstacles found when implementing the test. For the case study we will use instruments like the monitoring sheet to indicate the development of the Digital Literacy .

The data analysis format will be spreadsheets and statistical analysis software, like the statistical software PSPP (Free Software Foundation, Boston. EE. UU.), the R language or similar ones.

Population:

The Health professionals of the of East Health Management Area of Málaga-Axarquía, their digital reading-writing practices in the development of their professional role in the development of their professional role and in the individual-private field.

Target group: 1.300 workers belonging to all the professional categories in the area of Axarquía.

\section{RESULTS}

The present results have been extracted from a survey designed with the aim to explore the digital reading-writing habits and practices and the use of the Information and Communication Technologies to access electronic information; the way in which information is accessed, processed, saved, generated and disseminated.

The survey is based on the one devised by the E-lectra group of University of Salamanca [12] and the one designed by Tracy Gardner and Symin Inger [13]. The survey has been divided into 5 blocks:

The first block includes demographic data (gender, age, professional role/specialty, health area of action.

The second block inquiries about the use of e-journals in the field of the professional practice and training (time dedicated to consult, ways to access e-journals, places used to access ejournals, favorite places to access journals of special interest, sites frequently used to receive digital information, features and benefits assessed positively in e-journals).

The third part asks questions to know the types of access and tools used in documentary management (type of device used to access the Internet, file formats known and used frequently, use of applications, different types of storage and use of mobile devices).
The fourth block questions the use of e-books (places of access, devices used to access, professional and/or personal use, types of information resources used in the professional and/or personal practice, valuation of the validity and precision for the research and the scientific-technical tasks from different sources of digital/printed information, use of bibliography management software, conservation of documents).

The fifth block deals with the importance given to training in the use of electronic/digital resources, use and practice of digital reading and writing, participation in the social network and use of the blogosphere.

The survey was designed in Google Forms and is hosted in Google Drive [14] and the data processing has been done with the spreadsheet Excel.

Two types of surveys were distributed: A printed version and a digital one. The digital one was managed through the distribution lists used for selective dissemination of the information managed by the medical library of the Area of Axarquía. The survey version printed on paper was delivered by hand in the Clinical Management Units. The delivery of the surveys started on 24th February, 2016, and it still continues being delivered provided the information gathering is addressed to all the professionals of the East of Malaga Health Area (1300 professionals: doctors, nurses, sanitary technicians and service and administrative staff) and it hasn't been delivered in all the health assistance services and units yet. The present results are derived from those surveys received until 24th August, 2016. 281 people have answered the survey in a period of six months. The total number of test received was 281 .

\subsection{Demographic Data}

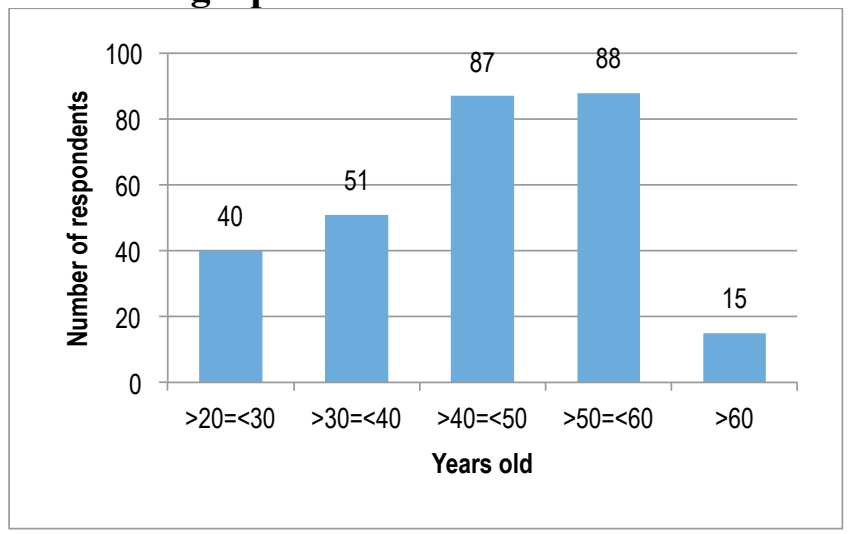

Figure 1. Age range of respondents

Most of the respondents, $62 \%$, are professionals aged 40 to 60 who know digital books and journals since the mid 90's, in the end of the Twentieth Century. Some of them have used these materials in the development of their professional practice just from 2006 onwards, the moment when the Virtual Library of the Andalusian Public Health Service of Andalusia was opened and the journals started being subscribed corporately only in its electronic format.

More than the $50 \%$ of the respondents were doctors in their training period; family doctors and/or specialist doctors. They are followed by the nurses and the administration workers. Other categories are the upper grade students and the professionals with undergraduate studies. 


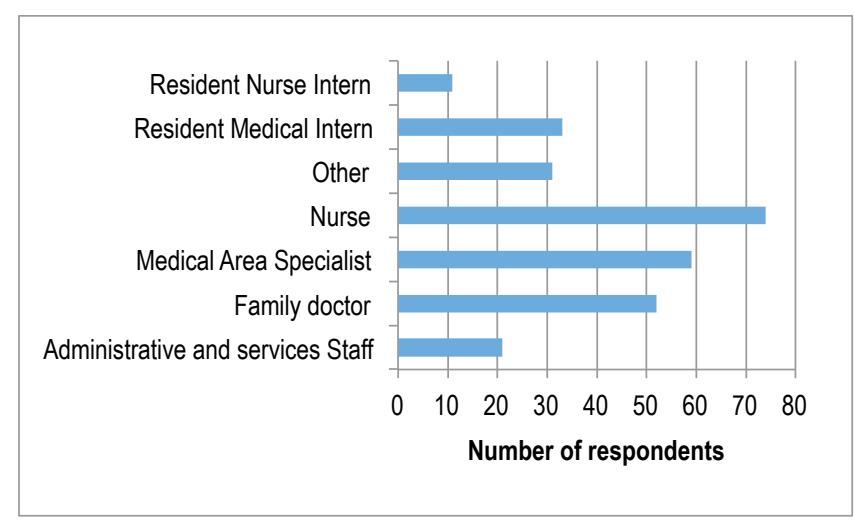

Figure 2. Professional role of respondents

\subsection{Management of e-journal in the professional practice}

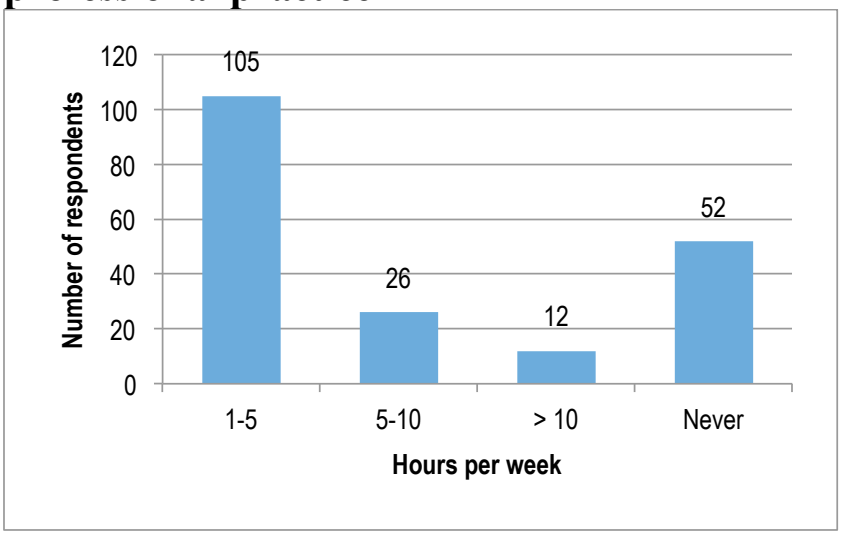

Figure 3. e-journal usage frequency

Although most of the professionals use journals, we have to highlight that the $18,5 \%$ don't know how to use electronic journals and the reasons why the $36 \%$ don't use them is that they don't know how to do it, followed by the $28 \%$ who state not to know where they can find them; the $25 \%$ prefer printed journals; a smaller percentage doesn't know where to find them in the library or declares that electronic journals are very difficult to use.

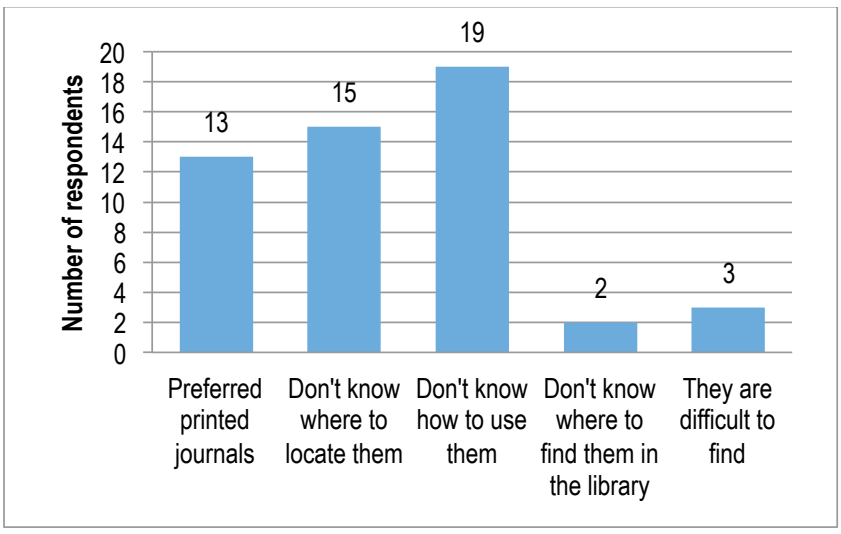

Figure 4. Reasons not to use e-journals

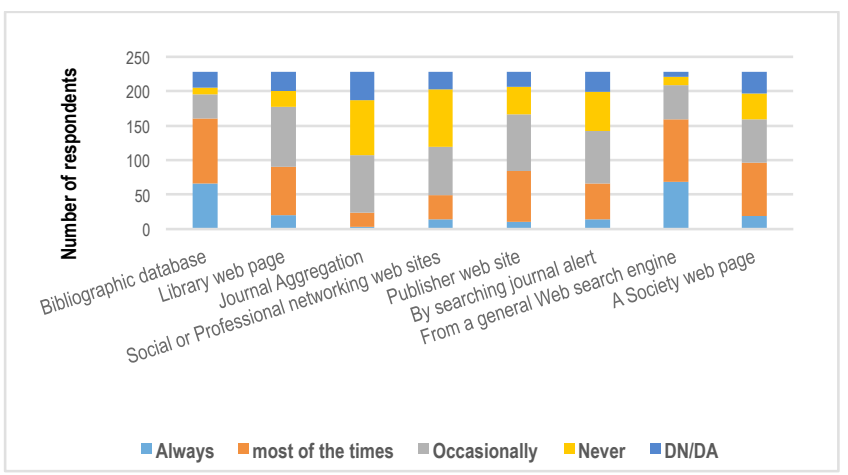

Figure 5. When you need to do a search for a specific article from an on line journal, where on the web do you start that search?

About the way to access e-journals, the data show that on finding an specific article, most of the times they do it using bibliographic data bases such as PubMed, EMBASE, Web of science, Scopus, etc., followed by a web search in google, and other Internet browsers. In the third place, the respondents mention the use of the editorials websites, the use of the social networks and the professional websites.

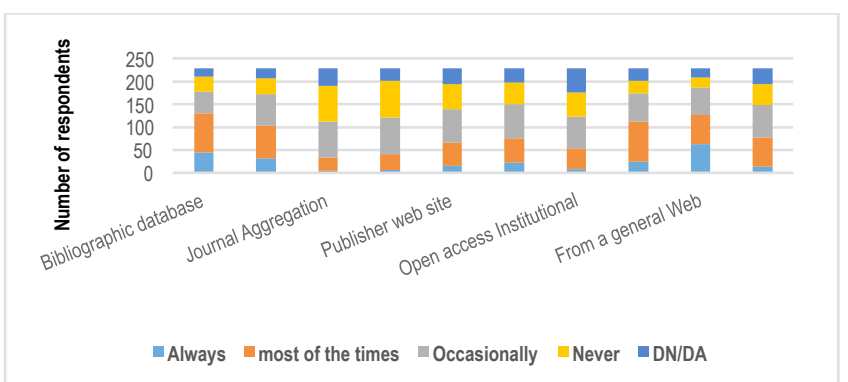

Figure 6. When you want to read the last issue of your favorite e-journal, where on the web do you start the search.

The answers about the different practices when using e-journals inform us that, it is done through an Internet browser, mainly Google. We understand that those searches are valid for the open access journals, but the subscription ones must be accessed through the Documentation Retrieval Service, and, therefore, through the Library. So, the library is being underused.

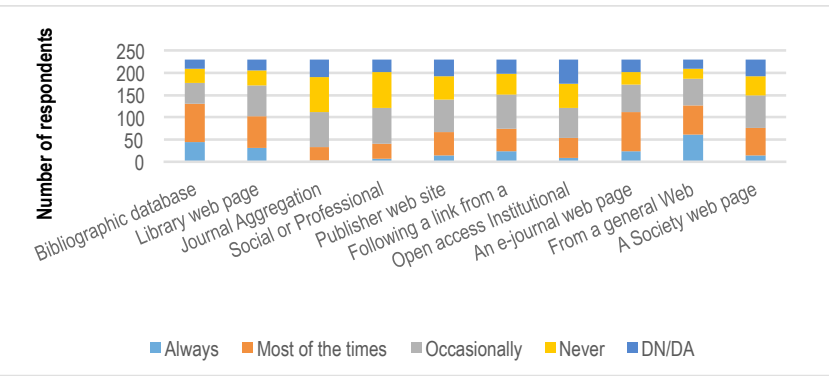

Figure 7. Way in which they access their favorite electronic journals.

The way they access a specific article is, in the first place, reading articles from their favorite journal; in the second place, searching for articles about an specific issue; in the third place, reading an article recommended by e-mail; in the fourth place, following a link in a saved alert. 


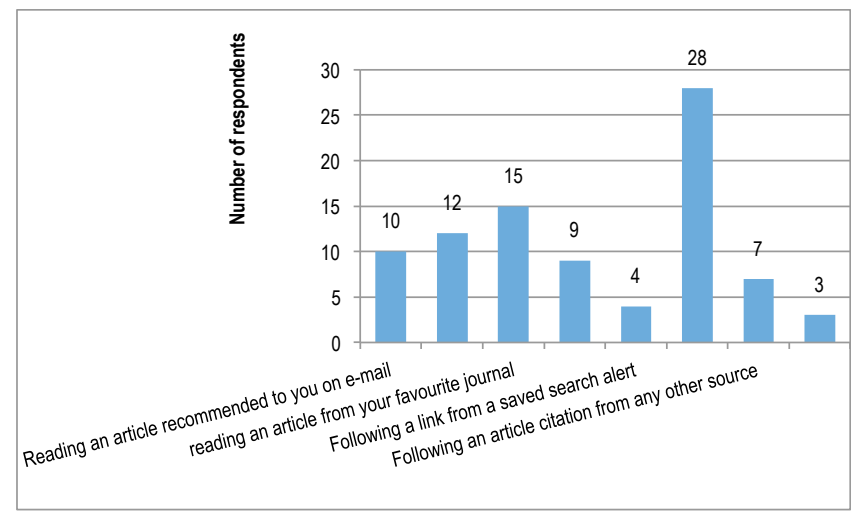

Figure 8. Ways to access e-journals the last time they were consulted.

About the type of access and the documentary management resources used to read the journals, the most used device to access the on-line articles is the computer, followed by the laptop, the mobile, the tablet, in that order, and seldom from the e-ink device e-reader.

As far as the type of electronic format known and used $(\mathrm{N}=251)$ is concerned, they answer that they know and use the pdf format, followed to a lesser extent by epub. Mobi is the next better know format although it is less used than the other two.

Regarding the use of mobile apps and the utilities integrated in the web browsers such as plugin, only the $23,8 \%$ use them, and the rest of the people declare not to use them and that they don't know them $(44,7 \%)$. The $23,8 \%$ uses the storage systems and the referral of articles to application ones. The $28,4 \%$ declare not to know these utilities and the $50 \%$ affirm not to use them although we don't know if they know them.

\subsection{Access to reference and document managers}

About the use of applications in the devices, the $62,4 \%$ don't use any applications and the $37,6 \%$ who use them, do it with eBook and pdfnotes. About the reasons that explain why the mobile applications are not used, the $43,7 \%$ state that it happens because they don't know them, and the $47,2 \%$ affirm that they don't like reading in a mobile device.

The $47 \%$ don't use electronic books in their personal or professional practice. The reason for not using electronic books is that they prefer printed books, declare not to know how to use them, don't know where to find them, add that electronic books are difficult to access, are not available in their areas of interest, are difficult to use and affirm that the library doesn't offer electronic books.

About the way to access, those who use electronic books affirm that they do mostly through general search engines, such as Google, followed by the library websites and its discovery tools. Then they do it from the general and bibliographic data bases, like PubMed, Scopus, Web of the Science, etc. They never do it from the network sites, books editors, etc. A meaningful number do it from libraries like google book, Amazon kindle and other libraries on the Internet.

Finding a specific book to use in the professional practice is mostly done through a general search in search engines on the Internet, like google (most of the times $\mathrm{N}=105$, always $\mathrm{N}=55$ ).
Then they use the library website. They hardly ever use the social networks and/or the providers' sites.

\section{4 e-Book management}

Information resources used in professional practice. Regarding the electronic resources used for the professional and personal practice, the printed books and magazines are the most frequently used. The electronic journals are the most demanded in the professional practice. They don't know the Google Scholar. For their personal use, they prefer the personal websites, the on-line newspapers, the networks and they don't use the podcasts or audio books.

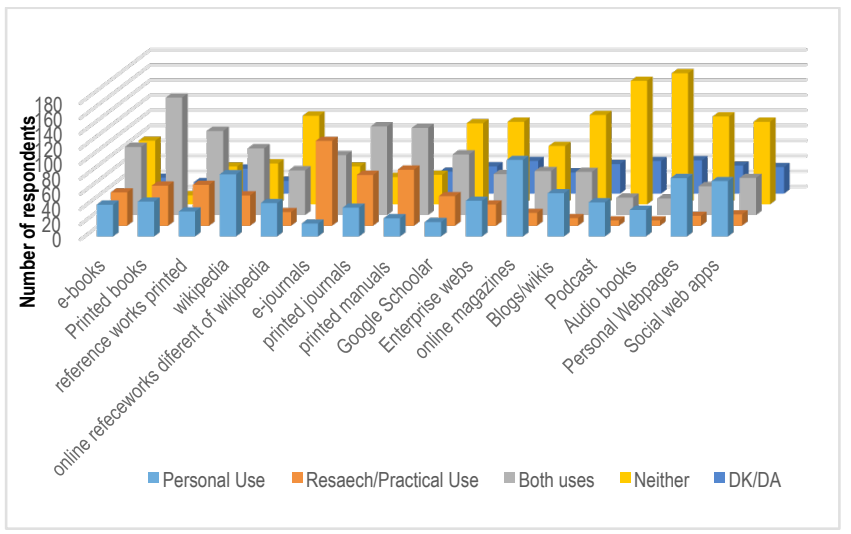

Figure 9. Information resources used in the professional and/or personal practice.

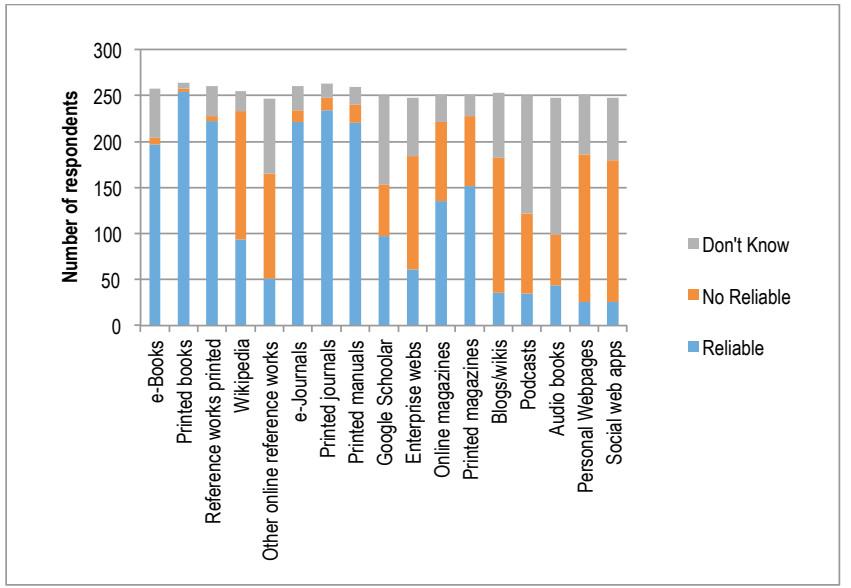

Figure 10. Valuation of the precision and validity given to the information resources.

They find reliable and trustworthy the books and journals, the manuals whatever their format is, printed/digital. They find less reliable the Wikipedia, the websites of the different companies, the blogs, podcasts, applications of the social web and the personal websites. A meaningful group admits not to know the Google Scholar, the blogs, podcast, audio books and personal websites.

As far as the device used to access the online books is concerned, the most frequently used is the computer, $(\mathrm{N}=96$ they do it most of the times, $n=91$ they always use it).

Most of the respondents use desktop and laptop computers most of the times, tablets and smartphones are still used in main way by a minority, e-readers are used scarcely. 


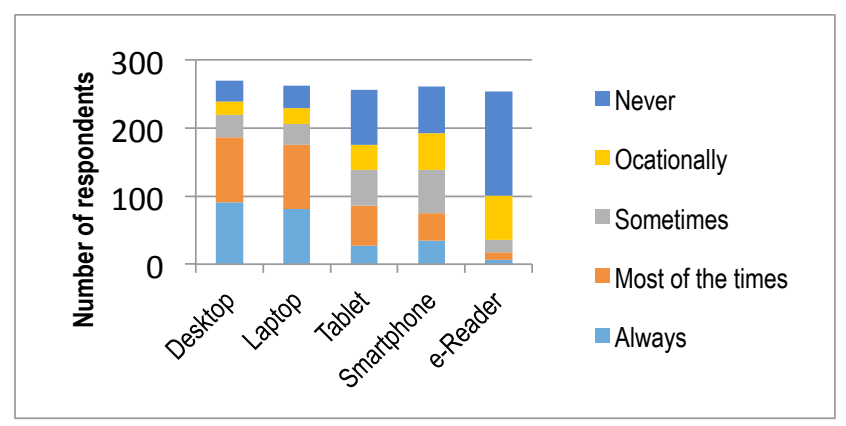

Figure 11. Device used to access the e-books.

About the use of bibliographic managers, only 19,4\% use them and the most frequently used is Zotero, followed by Mendeley and Endnote.

\subsection{Self-evaluation of resources management and use of the social network.}

Regarding their training, $49,6 \%$ of the respondents consider insufficient their knowledge of the digital resources, the $27,1 \%$ consider it good and $1,4 \%$ think it is excellent.

Here they comment the percentages and they highlight insufficient their training.

The $43 \%$ consider very important their training to know how to use the information resources, the $55 \%$ consider it very important and only the $1,8 \%$ feel it has little importance.

About the use of the social networks, the $77,4 \%$ use them frequently, the $22,6 \%$ don't use them. Considering the social networks where they have hosted their personal profiles, 93,8\% have a profile in a popular social network: Facebook, followed by Twitter (35\%), LinkedIn (31,3\%), Google Plus (22,6\%), ResearchGate (6,9\%) and, finally, Mendeley (4,6\%).

Regarding the use of digital writing in a blog, only $9,5 \%$ wrote in a blog.

\section{DISSERTATION STATUS}

The results which we are presenting are provisional and they presume some preliminary conclusions which are the result of the answers we have received to the survey we sent.

Previously, we did an analysis of the group of professionals of Health of the Management Area in Axarquía who are in a postgraduate training period. Its results were published in the 15 th European Association for Health Information and Libraries (EAHIL): Knowing the digital reading-writing habits of the Resident Medical Interns (RMI) in postgraduate training in the Health Area East of Malaga-Axarquia.

The professionals of health prefer searching for information using resources they are familiar with, followed by the discovery tools of the library, and they tend to start their search using general search engines, such as Google.

The respondents declare to find traditional publications, such as journal articles and/or digital or printed books, more reliable than other publishing alternatives like forums, wikis, podcast, wikipedia or publication in other media such as social networks.

The respondents know their lack of ability and competence in the use of digital information which is valued as poor or insufficient by most of them. They attach a lot of importance to training for the acquisition of these competences, and most of the respondents declare that their training is poor or insufficient, and they value training as important or very important in order to acquire the competencies that can derive from the Information Literacy.

In the research filed it is necessary that researchers know not only the formal methods for the transmission of knowledge but the informal ones too; communication channels, science 2.0 tools, open science, etc.

Digital reality has modified the practices to access information and knowledge. Getting to know this reality will allow us to adopt informed decisions to face the changes that are taking place in the knowledge society.

We are facing the emergency of a new reading and writing ecosystem which is changing the value chain developed since the invention of the printing press. Author, printer, editor, distributor, bookshop assistant, library, and reader constituted the ecosystem of the printed book. The digital book and journals have broken up this system that has lasted for five centuries giving way to documentary changes which have to be explored: the book considered as an object has turned into the book as a net [15] or the book as a service [16].

Teaching platforms and research, the appearance of digital support and the devices that provide access to the Internet and allow the management of information, its generation and dissemination, are in the origin of the changes in the reading and writing habits to the point of making inevitable the transition to the digital world [17]

The technological changes that have given way to the new ways to access scientific information and, particularly the way to access digital books and journals, producing changes and transformations in the way to process, save, generate and transmit knowledge. This change can be seen in the health science magazines which started the transfer to the digital edition in the year 1996, like, for example, the emblematic journal The New England Journal Medicine, which has recently has published a computer graphic about the new publication patterns in a monograph which celebrates the first 20 years of the journal in the web. (Figure 12). [18].

The International Federation of Libraries and Librarians (IFLA) [19] is aware of the changes that have occurred in the access to knowledge and that libraries must have a Literacy plan. Societies and professional schools are aware of this need, like the Royal College of Nursing in the UK, which has published a document about competencies ALFIN addressed to the nursing professionals; Finding, using and managing information: nursing, midwifery, health and social care information literacy competences[20].

The knowledge society requires new models and approaches in the educational processes that will allow us facing the challenges of a global society more and more dependent on the use of technology.

Our expectations about our future research is analyzing the training program the different training platforms of the Public Health System of Andalusia and suggest a training model in Information Literacy which contributes to make up for the possible deficiencies detected. 
On a preliminary study was observed that health professional on training demanded a specific formation on abilities on information literacy [21].

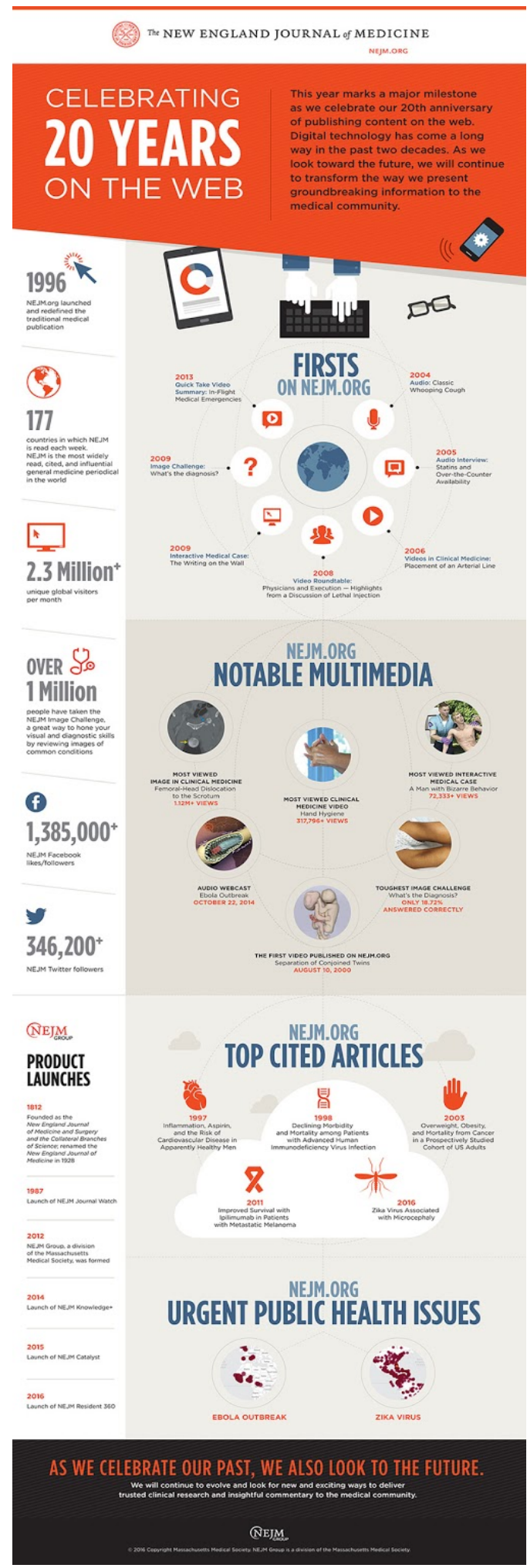

Figure 12. The New England Journal of Medicine celebrates 20 years on the web. Source: http://www.nejm.org/page/20years-nejm-online

\section{CURRENT AND EXPECTED CONTRIBUTIONS}

Finally, the conclusions of the research will be established in journals with international visibility and which are included in the Journal Citation Report: Professional of the Information; Spanish Journal of Scientific Documentation; JASIST Journal of the Association for Information Science and Technology; International Journal of Information Management.

Conferences: European Association for Health Information and Libraries (EAHIL) 2017,2018; TEEM 2017, 2018; IBERSID 2017.

\section{ACKNOWLEDGMENTS}

This research work has been carried out within the University of Salamanca $\mathrm{PhD}$ Programme on Education in the Knowledge Society scope (http://knowledgesociety.usal.es). Thanks to the directors of the thesis: Professor José Antonio Cordón García and Professor Raquel Gómez Díaz. Thanks also to Dr. Daniel Torres Olalla for his careful reading and helpful comments on English writing.

\section{REFERENCES}

[1] Alonso Arévalo, J., Gómez Díaz, R., Cordón García, J. A. Ebooks en bibliotecas: gestión, tratamiento y aplicaciones. Afagrama, Buenos Aires, 2015.

[2] Arévalo, J.A., 2013. La transición hacia los libros de texto digitales. Boletín de la Asociación Andaluza de Bibliotecarios 28, 264-268.

[3] Alonso-Arévalo, J., Cordón-García, J.-A., 2013. Lectura digital y aprendizaje: las nuevas alfabetizaciones WWW Document..

URL http://gredos.usal.es/jspui/handle/10366/122442 (accessed 9.12.16).

[4] Alonso Arévalo, J., Cordón García, J.A, 2015. El libro como sistema: hacia un nuevo concepto de libro. Cuadernos de Documentación Multimedia 26, 25-47. http://doi:10.5209/rev_CDMU.2015.v26.50628

[5] Cassany, D. Tras las lineas: Sobre la Lectura Contemporánea, Anagrama, Barcelona, 2016.

[6] Cassany, D. Prácticas letradas contemporáneas. Rios de tinta, Mexico, 2008.

[7] Chartier, R. Revoluciones de la cultura escrita. Ed. GEDISA, Barcelona, 2015.

[8] Marc Prensky, 2001. Digital Natives, Digital Immigrants Part 1. On the Horizon 9, 1-6. doi:10.1108/10748120110424816

[9] Cordón García, J.A, Gómez Díaz, R., Alonso Arévalo. J., Alonso Berrocal, L. El ecosistema del libro electrónico universitario, Ed. Universidad de Salamanca, Salamanca, 2014

[10] Cordón García, J.A., Carbajo Cascón, F.C., Gómez Díaz, R.G., Alonso Arévalo, J.A. Libros electrónicos y contenidos digitales en la sociedad del conocimiento: Mercado, servicios y derecho. Ed. Pirámide, Madrid, 2012.

[11] Johnson, R.B., Onwuegbuzie, A.J., 2004. Mixed Methods Research: A Research Paradigm Whose Time Has Come. Educational Researcher 33, 14-26. doi:10.3102/0013189X033007014 
[12] Fernández Gómez, M.J., Cordón-García, J.-A., AlonsoArévalo, J., Gómez-Díaz, R., 2014. Prácticas de consumo electrónico: los lectores ante los nuevos soportes WWW Document. http://gredos.usal.es/jspui/handle/10366/122817 (accessed 9.12.16).

[13] How Readers Discover Content in Scholarly Publications WWW Document, , n.d. URL http://www.simoningerconsulting.com/how_readers_discover .html (accessed 9.12.16).

[14] Uso y Acceso a libros y revistas electrónicos y otros recursos de digitales WWW Document., n.d. . Google Docs. URL https://docs.google.com/forms/d/e/1FAIpQLSczq3wIwBf1nC htB8sT6FeX1Mg64buK3GVU00Ij0f4VPkkELg/viewform?c $=0 \& \mathrm{w}=1 \&$ usp $=$ mail_form_link\&usp=embed_facebook (accessed 9.12.16).

[15] Gómez Díaz, R., García Rodríguez, A., Cordón García, J.A., Alonso Arévalo, J. Leyendo entre pantallas, 1st ed. Ediciones Trea, S.L.,Gijón, 2016.

[16] Alonso Arévalo, J., Cordón García, J., 2015. El libro como sistema: hacia un nuevo concepto de libro. Cuadernos de Documentación Multimedia 26, 25-47. doi:10.5209/rev_CDMU.2015.v26.50628
[17] País, E.E., 2016. Sobre lecturas, libros y lectores (digitales) WWW Document.. EL PAÍS. URL http://elpais.com/elpais/2016/01/10/opinion/1452441603_739 731.html (accessed 9.12.16).

[18] Campion, E.W., Scott, L., Graham, A., Prince, J.M., Morrissey, S., Drazen, J.M., 2016. NEJM.org - 20 Years on the Web. New England Journal of Medicine 375, 993-994. doi:10.1056/NEJMe1610607

[19] Publications from IFLA. Publications from Information Literacy. WWW Document., n.d. URL http://www.ifla.org/ES/publications/81 (accessed 9.12.16).

[20] Royal College of Nursing, n.d. Finding, using and managing information Nursing, midwifery, health and social care information literacy competences. https://www2.rcn.org.uk/_data/assets/pdf_file/0007/357019/ 003847.pdf

[21] Fernández-Luque, A.M., García-Navas, V., 2016. Knowing the digital reading-writing habits of the Resident Medical Interns (RMI) in postgraduate training in the Health Area East of Malaga-Axarquia WWW Document.. URL http://www.repositoriosalud.es/handle/10668/2387 (accessed 9.12.16). 